\title{
Determinants of Gold Price in the Short Term
}

\author{
Katarzyna Mamcarz*
}

\begin{abstract}
The goal of the paper is to characterize and assess the impact of the most important factors on gold prices in the short term, i.e. the purchasing power of the US\$, level of interest rates, official sector, seasonality, political events, media information and press releases. They influence the level of supply and demand in the gold market and, consequently, its prices. After presenting the specificity of gold as a metal and financial asset, a separate analysis of the effect of each of the foregoing factors was carried out. Depending on the character of the factor and available empirical data, the assessment of the influence of these factors on price changes used basic descriptive statistics, graphic charts and a descriptive analysis. The influence of individual factors differed, while the character of interrelationships between changes in these factors and gold prices did not always reflect the regularities known from the literature. This applies, in particular, to the purchasing power of the US\$ and the level of interest rates. To learn the force and direction of impact of these factors on gold price in the short term is of significant importance for investment in defining the moments of opening and closing the position in the market of this financial asset.
\end{abstract}

Keywords: gold price, purchasing power of the US\$, interest rates, official sector, seasonality

\section{Introduction}

When deciding to invest in gold it is essential not only to know its price but also the factors that influence it. The identification of these factors makes it possible to explain changes in gold prices in the past and to make forecasts. This is of great importance for both speculators and investors committing capital in the long term. Gold prices, however, are influenced by a comparatively larger number of factors than in the case of other assets. They cannot be simply reduced to one common denominator, which stems from the very nature of gold and its specificity. It is the only one metal of its kind. Gold is not only the object of investment but also industrial raw material, and a luxury consumer good (jewellery products); it still plays a significant monetary role although the gold monetary system was abandoned (central bank reserves), its price correlates with the price of other assets, it is comparatively rare in nature (as underground stock) whereas its over ground stock is still moderately sufficient compared with needs. The gold balance (supply and demand) also has it specific characteristics. They manifest themselves in that its stored stock may be far higher in relation to production needs than in the case of other raw materials which, despite being lower, require far greater expenses connected with financing raw material stocks. Compared with other

\footnotetext{
* dr Katarzyna Mamcarz, Uniwersytet Marii Curie-Skłodowskiej w Lublinie, Pl. M. Curie-Skłodowskiej 5, 20-031 Lublin, e-mail: katarzyna.mamcarz@poczta.umcs.lublin.pl.
} 
segments of financial markets, e.g. with the bonds market or hedge funds market, the gold market is very small, in addition. It can be surprising; therefore, that so much attention is devoted to such a small market (Bandulet 2010: 189).

There are short- and long-term determinants of gold price. In the short term these are: the purchasing power of the US\$, the level of interest rates, seasonality, official sector, political events, media information and press releases; in the long-term: an increase in the world population, investment demand, the volume of mining production, and the raw materials cycle. The foregoing factors influence the development of supply and demand in the gold market, thereby determining each change in its price. While short-term factors are important for investors in determining the moments of opening/closing a position, long-term factors are significant for strategic investment.

The objective of the paper is to characterize and estimate the impact of major factors on gold prices in the short term. Depending on the character of the individual factors and available empirical data, this assessment made use of basic descriptive statistics, graphic charts and descriptive analysis. Studies were carried out and based on empirical data published by the World Gold Council, Thomson Reuters GEMS, and those obtained from other Internet sources. The principal research period covers the years 2000 to 2013.

\section{The purchasing power of the US\$}

In world markets, gold is priced in US dollars and, consequently, no other factor determines its prices so much as the condition of the American financial system. This is due to the fact that the US dollar is not only the leading currency for gold trading but also the world's essential reserve currency. Gold is the natural opposite of the paper dollar treated as the antidollar. Its price correlates negatively with the US dollar. The purchasing power of the US\$ weakens, the price of gold rises, and vice (Hammoudeh et al. 2009; Pukthuanthong, Roll 2011). The measure of the dollar's purchasing power (money) is, on the other hand, the reverse of the indicator of the general price level (inflation rate). The potential increase in gold prices thus depends on the level of and changes in the dollar's purchasing power determined by inflation (Figure 1).

Figure 1 shows that the effect of changes in the purchasing power of the US dollar on the price of gold was not as explicit as has been said above. Except for the last year, both increases and drops in the US\$ purchasing power were accompanied by increases in gold prices basically all the time. A negative correlation of the gold price and the US\$ purchasing power was clearly seen at least at the beginning (from 2000 to 2005) and at the end (2010 to 2011) of the gold bull market, and in 2013. At that time gold prices were inversely proportional to the US\$ purchasing power, yet there were also periods during which the gold price changed regardless of or even against its purchasing power. The longer the gold bull market lasted, the more its price began to "move away" from the dollar. This happened in 2009 after the US Government introduced a billion-dollar rescue package to protect the 
badly crisis-stricken financial sector from collapsing, and in 2012. As a result, the correlation co-efficient had a small but positive value $(\rho=0.26)$, and the determination co-efficient $-\mathrm{R} 2=0.0676$. Therefore, the purchasing power of the dollar was not a significant factor determining the price of gold.

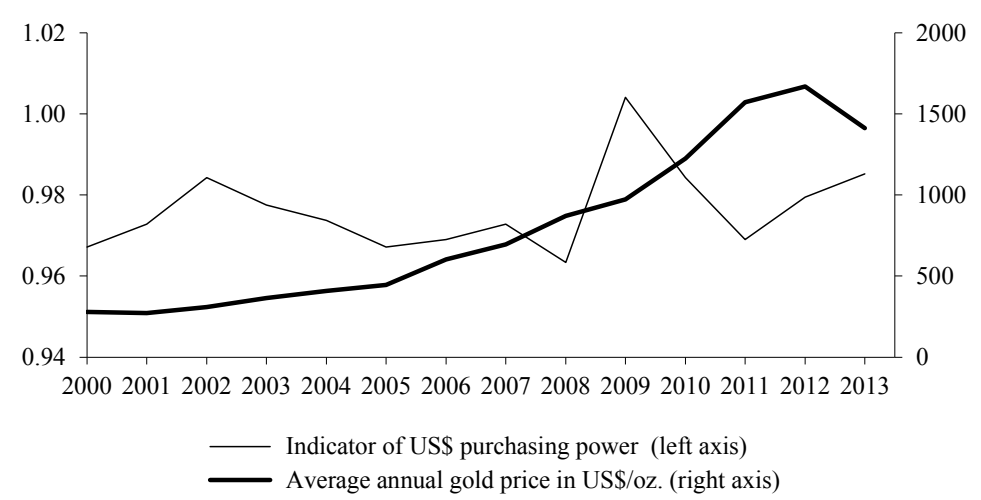

Figure 1. The indicator of US\$ purchasing power and the average annual gold price in 2000-2013 Source: based on the World Gold Council; US Inflation Calculator.

Changes in the US\$ purchasing power have their impact on its exchange rate and thereby on gold prices in national currencies. When the US\$ exchange rate strengthens, then ceteris paribus the purchasing power of national currencies declines. The gold prices in these currencies automatically rise and, consequently, the rates of return decline. In contrast, a weak dollar makes gold in other currencies comparatively inexpensive and conducive to increased returns on investment. This also produces the reaction of international capital markets, in which a growing interest in gold can be observed. The gold market then attracts comparatively many investors, which increases its price (Table 1).

Table 1 shows that the highest rate of return was obtained by investors who conducted transactions in GBP (12.01\%), with a standard deviation of $17.64 \%$, the lowest return rate being obtained in CHF transactions (7.33\%), with a standard deviation of $14.67 \%$. In the initial period of the last gold bull market, which began in April 2001 (on 2 April 2001 the lowest gold price was recorded at $255.95 \mathrm{US} \$ / \mathrm{oz}$.) after the long-lasting stagnation in the 1990s, investors who conducted transactions in US\$ obtained considerable rates of return (years 2002 to 2004) as compared with other currencies (EUR, JPY, GBP, CHF). During the second stage of the bull market (from 2005 to 2007) the dollar exchange rate weakened, the price of gold rose faster, however, and it slowly grew in price also in other currencies. This still resulted in high rates of return both in dollars and in these currencies. In the next stage of the bull market, which began during the crisis years of 2007 to 2009 and lasted until September 2011 (on 6 September 2011 the highest price was recorded at 1,895.00 US\$/oz.), and except in 2008, comparatively high rates of return were obtained. After the collapse of 
the gold market in 2011 investors began obtaining lower and lower or even negative rates of return (2013).

Table 1

Rates of return on gold investment (in selected world currencies) in 2000-2013 (\%)

\begin{tabular}{lrrrrr}
\hline Years & \multicolumn{1}{c}{ US\$ } & \multicolumn{1}{c}{ EUR } & \multicolumn{1}{c}{ JPY } & \multicolumn{1}{c}{ GBP } & CHF \\
\hline 2000 & -5.44 & 2.25 & 6.45 & 2.78 & -3.13 \\
2001 & 0.75 & 6.23 & 15.62 & 3.41 & 3.22 \\
2002 & 25.57 & 6.54 & 13.70 & 13.52 & 4.57 \\
2003 & 19.89 & -0.26 & 8.27 & 7.82 & 7.23 \\
2004 & 4.65 & -1.94 & 0.45 & -1.56 & -2.86 \\
2005 & 17.77 & 34.40 & 35.12 & 30.56 & 35.20 \\
2006 & 23.20 & 10.20 & 24.37 & 8.06 & 14.11 \\
2007 & 31.92 & 18.98 & 23.69 & 29.71 & 22.35 \\
2008 & 4.32 & 9.72 & -15.35 & 44.43 & -1.93 \\
2009 & 25.04 & 21.14 & 28.41 & 11.32 & 21.44 \\
2010 & 29.24 & 38.77 & 13.42 & 34.94 & 16.80 \\
2011 & 8.93 & 12.12 & 2.59 & 8.40 & 9.03 \\
2012 & 8.26 & 6.60 & 21.67 & 3.51 & 5.98 \\
2013 & -27.33 & -30.47 & -11.66 & -28.68 & -29.39 \\
Mean & 11.91 & 9.59 & 11.91 & 12.01 & 7.33 \\
SD & 15.55 & 16.07 & 14.09 & 17.64 & 14.67 \\
\hline
\end{tabular}

Source: based on World Gold Council.

\section{The level of interest rates}

In physical terms gold as an investment does not yield interest, which is the reason why many investors deposit money in banks. Paper money accepted as a legal tender guaranteed by the State may over time lose in value because of inflation. Inflation leads to the depreciation of paper money and a decrease in its purchasing power. The interest on paper money deposits is expected to compensate for that. It is paid according to the current nominal interest rate comprising the real interest rate and inflation premium (Gup, Brooks 1997: 22).

The effective yield on savings, which is a difference between the nominal interest rate and inflation rate, is the real interest rate. During the periods of comparatively low or, in particular, negative interest rates, investors seek other possibilities of capital investment in order to avoid losses (Starr, Tran 2008). Gold, which does not yield interest, then becomes interesting as compared with bank deposits and fixed interest rate securities. There follows a considerable demand for gold, and its price clearly rises. Conversely, very high real interest rates make investment in gold seem unattractive to many investors. The interest in bonds then grows and the price of gold should drop. The increase in nominal interest rates is always caused, however, by the rising inflation rate, while the fear of inflation increases the 
demand for gold and, consequently, its price. In the past, rising inflation rates were therefore always an important indicator of rising gold prices. The past showed clearly, though, that the rising price as an inflation effect compensates more than enough for the declining attractiveness of gold in relation to bonds, and the price of gold rises (Sieper 1991: 274).

In order to analyse the foregoing relationships this study adopted the nominal rates of return of 10-year US bonds to calculate real interest rates. These bonds are representative of the bond market and are used as a benchmark for other financial investments (10-year government benchmark bond yield). Changes in the level of real interest rates and gold prices between 2000 and 2013 are illustrated in Figure 2.

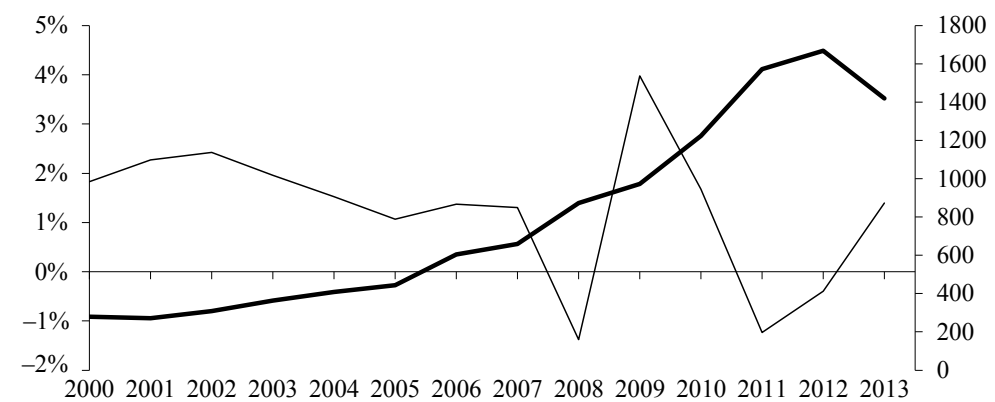

20002001200220032004200520062007200820092010201120122013

- Real interest rate (left axis)

- Average annual gold price in US\$/oz. (right axis)

Figure 2. The real interest rate and the average annual gold price in 2000-2013

Source: based on the World Gold Council; US Inflation Calculator; EBC.

Figure 2 shows that significant fluctuations in real interest rates were accompanied all the time, except in 2013, by rising gold prices. The low and declining, or even negative real interest rates made gold an increasingly attractive investment, and its price rose. The correlation coefficient had a negative value $\rho=-0.49$, the determination coefficient $R^{2}=0.2401$. In 2009 and in 2012, however, gold did not respond with a drop in price despite an increase in real interest rates. This effect occurred only in 2013.

For thousands of years gold has been used as money and has retained the monetary role of keeping value. Gold, the real money with a zero interest rate, is an attractive investment if, under the conditions of inflation, it can keep at least the real value (Bergold, Eller, eds. 2006: 258). Under the paper money system the gold price should therefore follow inflation or even anticipate it. The task of gold price has always been to offset inflation (Bandulet 2010: 176) ${ }^{1}$. Changes in the nominal and real prices of gold are illustrated in Figure 3.

\footnotetext{
${ }^{1}$ For example, since 1933 the US dollar has lost $94 \%$ of its purchasing power whereas approximately both then and now an ounce of gold can buy quite a good suit. For two hundred years, when the gold money system was the established one in the UK, the purchasing power of the British currency fell by $10 \%$ only. The recent financial crisis
} 


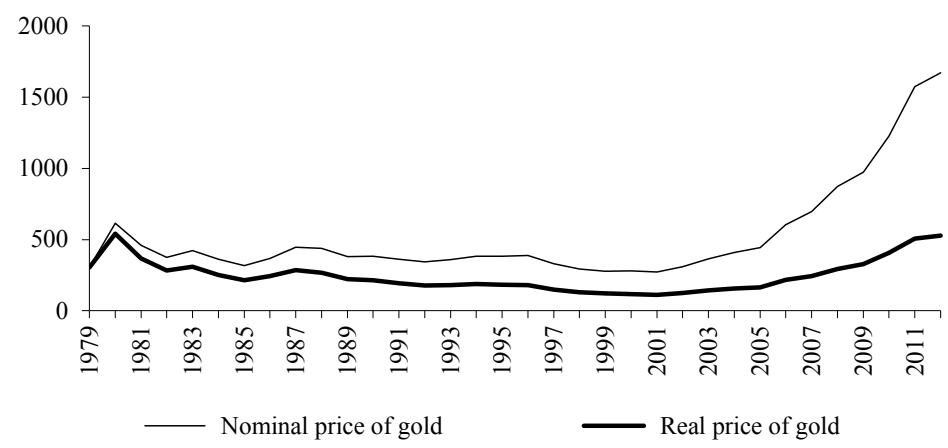

Figure 3. The nominal and real price of gold in 1979-2012 (in US\$/oz.)

Source: based on Gold Survey (2013): 113, 114 .

Figure 3 shows that a sudden surge in the gold price in nominal terms took place during the bull market after 2001. The factors that determined the demand for gold and its price were the abovementioned decrease in the profitability of bonds and increasingly declining interest rates. What was also conducive to the rising demand was certainly the bear stock market also reported during that period. The real price of gold was below its nominal price. A particularly large spread was reported during the bear gold market. Nevertheless, despite a temporary decrease, gold kept its real value.

\section{The official sector}

The official sector comprises transactions in gold (sales and purchases) by governments and central banks. Gold, which plays a vital monetary role, has long been linked with the functioning of these institutions. In the long history of gold in this capacity an important event was the introduction, after WW2, of the Bretton Woods currency system, in which the paper money in circulation would be backed by gold and hard currency. It was a system of fixed exchange rates between individual currencies, the dollar, and gold. After the USA unilaterally suspended the obligation to exchange dollars for gold in August 1971, the official price of gold, expressed in US dollars, was finally abandoned. The system of floating currency exchange rates, which had already been used for a long time, became a fact. Gold lost its significance in the world's money markets as a quasi-substitute of currency (Ostrowska 2011: 209). The period of its continuing sale began, which caused strong pressure on a drop in its prices. The oversupply of gold produced by sales by the official sector accounted inter alia for low prices in the 1990s.To sum up, the result was stagnation in the gold market. 
A further decrease in gold prices was not in the interests of the issuing banks. On 26 September 1999, the first agreement between fifteen central banks (Central Bank Gold Agreement, CBGA), also known as the Washington Agreement on Gold, took place. The CBGA (1) agreement was in force for five years. However, on 8 March 2004 its earlier renewal was announced as the CBGA (2), whose validity date was 26 September 2009. It was subsequently renewed on 7 August 2009 for another five years. The essence of these agreements were arrangements to limit gold sales by central banks, signatories to the agreements, which undertook to limit the sale of their reserves to: CGBA (1) - 400 tons, CGBA (2) - 500 tons, and CGBA (3) - 400 tons of gold per year respectively (the World Gold Council). The announcement of the first CBGA agreement caused a spectacular speculative bubble in the fall of 1999. Gold prices suddenly surged almost overnight, and then dropped to stabilize at a low level (Gburek 2003: 36)2. In April 2001 the downward trend was at its lowest (2 April $2001-255.95$ US\$/oz.), followed by the period of the bull gold market. In the last decade, the official sector both bought and sold gold, which had its impact on gold price (Tab. 2).

\section{Table 2}

Gold purchases and sales by the official sector, and gold prices in 2003-2013

\begin{tabular}{lllllc}
\hline Yrs & $\begin{array}{l}\text { Net official sector } \\
\text { transactions (tons) }\end{array}$ & $\begin{array}{l}\text { Price of gold (annual } \\
\text { average in US\$/oz.) }\end{array}$ & Yrs & $\begin{array}{l}\text { Net official sector } \\
\text { transactions (tons) }\end{array}$ & $\begin{array}{l}\text { Price of gold (annual } \\
\text { average in US\$/oz.) }\end{array}$ \\
\hline 2003 & 620 & 363.32 & 2009 & 34 & 972.35 \\
2004 & 479 & 409.17 & 2010 & $(77)$ & 1224.52 \\
2005 & 663 & 444.45 & 2011 & $(457)$ & 1571.52 \\
2006 & 365 & 603.77 & 2012 & $(544)$ & 1668.98 \\
2007 & 484 & 695.39 & 2013 & 409 & 1411.23 \\
2008 & 235 & 871.96 & & & \\
\hline
\end{tabular}

Source: based on Gold Survey (2013): 8; Gold Survey (2014): 8.

During the analysed period between 2003 and 2009, gold sales by the official sector were larger than its purchases (the annual average being 411 tons). This certainly slowed down the bull market for gold, yet the downward trend of this advantage resulted in rising prices. Consequently, the correlation coefficient between the net sales level and the price had a negative value $(\rho=-0.91)$, and the determination coefficient $R^{2}=0.8281$. The situation changed in 2010 when central banks started to rebuild their currency reserves. They bought more gold than they sold (figures in brackets, the annual average - 359 tons), thereby causing an increase in its prices. It was only in 2013 that banks sold more gold than they bought. Gold reserves will always be kept, however, by the official sector for political reasons, thereby constituting its potential supply. To sum up, it should be said that as long as monetary gold is used as currency reserves, the impact of governments and central banks on its supply and

\footnotetext{
${ }^{2}$ The price of gold stood at: 255.20 US\$/oz. (21 September 1999), 317.20 US\$/oz (29 September1999) and 326.25 US\$/oz. (5 October1999), (KITCO).
} 
demand as well as prices cannot be ruled out. This aspect of the market should be taken into consideration in forecasting gold price developments.

\section{Seasonality}

The gold market, like a number of other markets of financial assets, is characterized by seasonality in the evolution of the prices of this metal. Seasonality indicators show, however, that the gold price did not significantly deviate from monthly averages (Figure 4).

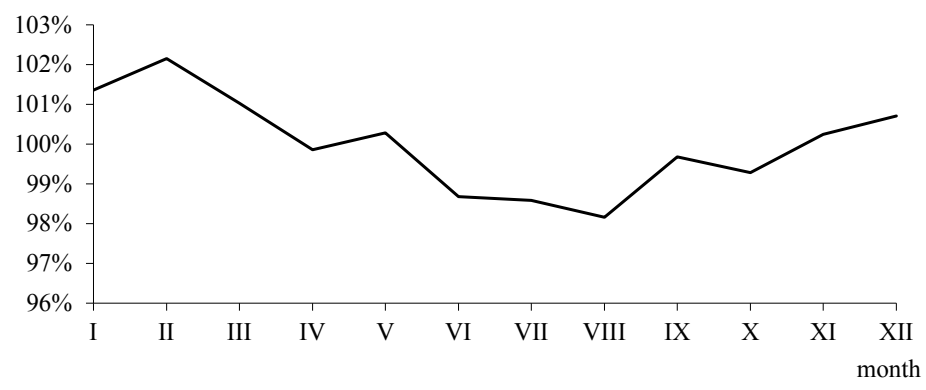

Figure 4. The indicator of seasonal fluctuations of gold prices in 2000-2013

Source: based on USAGOLD.

During the analysed period the price of gold higher than the monthly average was reported in the first three months of the year: by $1.36 \%$ (January), 2.15\% (February) and by $1.03 \%$ (March). In contrast, three consecutive months were regularly characterized by low prices, i.e. June, July and August. At that time the price was lower than the monthly average by $1.32 \%, 1.42 \%$ and by $1.84 \%$ respectively. ${ }^{3}$ In these months there is a decrease in demand and stagnation in the gold market. In summer, the Western world begins holidays whereas the Asian market is only expecting crops. The upturn in the gold market begins there in August/ September and lasts for the following months. The increase in the price of gold is reinforced by purchases of jewellery at the end of the year, in particular before Christmas. These price increases still hold in January and February (carnival) and then there are price corrections lasting until August with minor fluctuations. The observed seasonality in price developments may have also stemmed from the growing demand for jewellery in connection with the wedding period in India, which has its beginning and peak in October and lasts until May, and then wanes in the summer months (Schwarze 2010: 86). The graph of seasonality indices also shows that the local price minimums occur in April, August, and October. These months, particularly October, are therefore the right ones to open a position in the gold market from the tactical perspective. In the case of seasonality in the gold market, of significance are first of all trends in the changes in the price level in particular months be-

\footnotetext{
${ }^{3}$ Own calculations based on USAGOLD.
} 
cause, due to the special character of gold, there may always be a number of external factors that distort gold prices. The cause of slight seasonality in gold price developments appears to be the fact that there was a huge boom in the gold market during the almost whole period analysed.

\section{Political events, media information and press releases}

Gold is not only a monetary metal but also a "political" one. Political events are just as important for the changes in and the level of its prices as the amount of money and interest rates. To be precise, this refers to the US dollar - the currency in which gold is priced. The monetary and currency policy of the United States is subordinated to the requirements of its world policy. This applies to funding military operations in the Middle East, resulting in the increased deficit of the state budget on account of arms expenditure and the easy money policy. This also concerns the role of Japan and China as creditors of the United States because without their credits it would be difficult to finance the living standards of the American population and the development of the military sector. On the other hand, US military power certainly strengthens the dollar as a currency. Investors in international markets are always more impressed by the demonstration of power at the expense of not respecting the rights of nations (Bandulet 2010: 238). Because of political events threatening (especially global) peace, and also on account of other important events with a similar significance, there were temporary, slight increases in the price of gold. For example: a Kuwait ship was fired at by an Iraqi gunboat (December 2003), the Danish and French "no" to the European Constitution (May 2005), the beginning of riots in Paris (October 2005), Israel's attack on Lebanon (July 2006 ), the first test of a nuclear rocket carried out by North Korea (October 2006), the beginning of the Israeli-Palestinian conflict in the Gaza strip (December 2008), or the firing on South Korea by North Korea (November 2010), (Gold Survey 2013: 115-120). It should be added, however, that while gold used to be a par excellence "crisis metal", at present there is certain resistance of its price against adverse political events. Even the political destabilization of the Soviet Union, and the war between the US and Iraq determined the price of gold to be negligible (Sieper 1991: 275). This also applies to the recent events in Ukraine. Gold is becoming a "safe haven" under the conditions of extreme uncertainty, with a reservation that this applies to the short term (Baur, McDermott 2010).

In the short term, the price of gold may also be influenced by all kinds of media information and releases in the press, and rumours. In the case of adverse signals ${ }^{4}$ there was often panic among investors and increased purchases of gold, and, consequently, prices went up. This happened, for example, after the terrorist attack on the Marriot Hotel in Jakarta (August 2003), after China disclosed its intention to increase its gold reserves (April 2009),

\footnotetext{
${ }^{4}$ A telling example is the terrorist attack in the Indian financial metropolis of Mumbai in 2008, following which the population did not dare to appear on the streets for days and weeks, and all trading in gold practically came to a halt (Schwarze 2010: 85).
} 
after Standard \& Poor downgraded the US credit rating to AA+ (August 2011). Examples of items causing a decline of gold prices are: the announcement, by the Bank of France, of the potential sale of 500-600 tons of gold (June 2004), the tsunami in southern Asia (December 2004), the beginning of recession in Germany, Japan, and France (July 2009), and the IMF's announcement to sell 403.3 tons of gold (September 2009), (Gold Survey 2013: 116-121). The foregoing factors produce a definite market reaction on the supply and demand side, particularly because a large part of the gold market is not transparent.

\section{Final remarks}

The price of gold in the short term is determined by many factors, the most important being: the purchasing power of the US\$, the level of interest rates, the official sector, seasonality, political events, media information and press releases. These factors determine the levels of supply and demand in the gold market and, consequently, its price. The impact of particular factors was diverse, and the nature of relationships between changes in the factors and the price of gold did not always reflect the regularities known from the literature. With changes in the level of the purchasing power of the US\$ there were longer periods in which gold prices were set regardless of or even against the purchasing power of this currency. Closer to the expectations of investors, which stem from their knowledge of the regularities in this field, was the response of the gold price to changes in the level of real interest rates; the correction had a negative value but the determination coefficient was at a low level. Considerable fluctuations in interest rates did not also cause a decrease in the real value of gold. The impact of the measures by central banks can be defined as correcting the gold bull market. Any distinct seasonality in the development of gold prices, as well as the special influence of all kinds of events and information on the gold price were also not seen.

\section{References}

Bandulet B. (2010), Das geheime Wissen der Goldanleger, 3. Auflage, Kopp Verlag, Rottenburg.

Baur D. McDermott T. (2010), Is gold a safe haven? International evidence, "Journal of Banking and Finance" vol. 34, no. 8, pp. 1886-1898.

Mezger M. (2006), Die Preisbildung an Rohstoff-Terminmärkten, in: U. Bergold, R. Eller, Investmentstrategien mit Rohstoffen, WILEY-VCH Verlag, Weinheim

Gburek M. (2003), Das Goldbuch, FinanzBuch Verlag, 1. Auflage, München.

Gold Survey (2013, 2014), Thomson Reuters GFMS, London.

Gup B., Brooks R. (1977), Zarzadzanie ryzykiem stopy procentowej, Związek Banków Polskich, Warszawa.

Hammoudeh R., Sari B., Ewing B. (2009), Relationships among strategic commodities and with financial variables: a new look, "Contemporary Economic Policy" vol. 27, no. 2, pp. 251-264;

Ostrowska E. (2011), Portfel inwestycyjny, Wydawnictwo C.H. Beck, Warszawa.

Pukthuanthong K., Roll R. (2011), Gold and the Dollar, "Journal of Banking and Finance” vol. 35, no. 8, pp. 20702083.

Schwarze N. (2010), Investieren in Gold, 1. Auflage, FinanzBuch Verlag, München.

Sieper H. (1991), Geldanlage professionell, Gabler Verlag, Wiesbaden. 
Starr M., Tran K. (2008), Determinants of the Physical Demand for Gold: Evidence from Panel Data, "World Economy" vol. 31, no. 3, pp. 415-436.

KITCO, www.kitco.com/gold.londonfix.html (1.03.2014).

European Central Bank, http://sdw.ecb.europa.eu/quickview.do?SERIES_KEY=143.FM.M.US. USD.RT.BB. US10YT_RR.YLDA\&start=\&end $=\&$ trans $=$ YPC\&submitOptions. $x=0 \&$ submitOptions. $y=0$ (1.03.2014)

USAGOLD, www.usagold.com/reference/prices/goldhistory.php (1.03.2014)

US Inflation Calculator: www.usinflationcalculator.com/inflation/consumer-price-index-and-annual-percent-changes-from-1913-to-2008 (1.03.2014).

World Gold Council, www.gold.org/investment/statistics/demand_and_supply_statistics (21.01.2014).

\section{DETERMINANTY CENY ZLOTA W OKRESIE KRÓTKIM}

Streszczenie: Celem artykułu jest charakterystyka i ocena wpływu najważniejszych czynników na cenę złota w okresie krótkim, tj. siły nabywczej USD, poziomu stóp procentowych, sektora urzędowego, sezonowości, wydarzeń politycznych, informacji i komunikatów prasowych. Kształtują one poziom popytu oraz podaży na rynku złota i w konsekwencji jego cenę. Po przedstawieniu specyfiki złota jako metalu i aktywa finansowego przeprowadzono odrębną analizę oddziaływania każdego z wymienionych czynników. W ocenie wpływu tych czynników na kształtowanie się ceny wykorzystano, w zależności od charakteru danego czynnika i dostępności danych empirycznych, podstawowe statystyki opisowe, wykresy graficzne oraz analizę opisową. Wpływ poszczególnych czynników był zróżnicowany, a charakter zależności między zmianami tych czynników i ceną złota nie zawsze odzwierciedlał znane z literatury prawidłowości. Dotyczyło to zwłaszcza siły nabywczej USD oraz poziomu stóp procentowych. Poznanie siły oraz kierunku oddziaływania tych czynników na cenę złota w okresie krótkim ma istotne znaczenie dla inwestycji w aspekcie określania momentów otwarcia i zamknięcia pozycji na rynku tego aktywa finansowego.

Słowa kluczowe: cena złota, siła nabywcza USD, stopy procentowe, sektor urzędowy, sezonowość

\section{Citation}

Mamcarz K. (2015), Determinants of Gold Price in the Short Term, Zeszyty Naukowe Uniwersytetu Szczecińskiego nr 855, „Finanse, Rynki Finansowe, Ubezpieczenia” nr 74, t. 1, Wydawnictwo Naukowe Uniwersytetu Szczecińskiego, Szczecin, s. 127-137; www.wneiz.pl/frfu. 
